\title{
CHALLENGES FOR AGRICULTURAL POLICY IN THE SERVICE- DRIVEN ECONOMIC SYSTEM
}

\author{
Dalia Vidickiene ${ }^{1}$, Zivile Gedminaite-Raudone ${ }^{2}$ \\ *Corresponding authorE-mail: zivile.gedminaite@laei.lt
}

A R T I C L E I N F O
Review Article
Received: 12 September 2018
Accepted: 01 October 2018
doi:10.5937/ekoPolj1804545V
UDC 338.43:330.342

Keywords:

Service-driven economic system, servitization, business model, post-industrial stage, agrarian and rural development policy

JEL: B00, O1, O13, P50

\section{A B S T R A C T}

During last decades the essential shift occurred in the structure of the economy from industrial product-driven to the post-industrial service-driven economic system. A growing number of manufacturing firms throughout the world are shifting from selling goods to offering more and more services alongside their products. This movement is termed the "servitization". The movement is pervading almost all industries but still is weak in agriculture. The aim of the paper is to draw an agricultural sector-specific picture of servitization and discuss the differences between the business models of product-driven and service-driven farms. Servitization of farming is a transformational process that requires rethinking all aspects of the business: production structure and methods, marketing, pricing, service delivery infrastructure and financial management. The aims and means of current agricultural policy should be transformed in accordance with the emerging new business vision of the post-industrial farmers' generation. The article analyses the needs and perspectives to develop agricultural policy in line with the success factors of the service-driven economic system and highlights the main new post-industrial rural policy trends, which corresponds to the needs of new farmers' generation oriented towards servitization of farming in the new programming period after 2020.

(C) 2018 EA. All rights reserved.

\section{Introduction}

The 21 st century is often described as a stage of post-industrial or knowledge society, where people found themselves in a world of totally different values, compared to the several centuries lasted industrial era. In the present stage of the post-industrial society the factors of economic success are essentially different from those in the industrial society, with the difference being as great as between the factors affecting the economic success of the agrarian and industrial society. This stage began when the service

1 Dalia Vidickiene, Lithuanian Institute of Agrarian economics, V. Kudirkos st. 18-2, 03105 Vilnius, tel. +370 5261 3169, e-mail: dalia.vidickiene@laei.lt

2 Zivile Gedminaite-Raudone, Lithuanian Institute of Agrarian economics, V. Kudirkos st. 18-2, 03105 Vilnius, tel. +370 5261 3169, e-mail: dalia.vidickiene@laei.lt 
sector have started to dominate in the economic system. These changes can be clearly illustrated by an example of data of the Organization for Economic Cooperation and Development (OECD) - service sector of 16 OECD countries amounted on average 39 percent in economic structure in the years 1950-1960 and in the next years of 19902000 increased until 70 percent, when the share of the agrarian sector has decreased from 25 percent until 4 percent in the same periods (OECD, 2006). Changes occurred not only in the traditionally classified economic structure. In the last decade of 20th century revealed new tendency to provide services not only by specialized service companies but also by industrial or agricultural enterprises. This new tendency to organise business was called "servitization". The term "servitization" was mentioned firstly in the article "Business servitization: increase of the value by increasing the volume of services" in 1988 written by S. Vandermerwe and J. Rada. Subsequently, this concept has become more and more widely used in academic and professional business literature, and has become one of the most popular newcomers describing the "new economy' over the last couple of decades.

The servitized economy forms a new stage in the development of society, essentially different from the previous one - the industrial stage. Disparities in the post-industrial stage are becoming more and more evident every day and can be compared to the previous major transformation of the economic system development from the agrarian to the industrial stage, so-called 'industrial revolution'. However, the concepts of the industrial economy are still used while analysing activities of the agricultural sector and innovations related with specifics of the post-industrial stage are not defined as servitization of farming. For example, all efforts made by farmers to apply new business models to respond to the needs of consumers for fresh, locally produced food are defined as the desire to shorten food supply chain. However, the business model when farmers take direct sales in order to reduce the number of intermediaries involved in the supply chain are fundamentally different from the transformations of the business model when an industrialized agricultural producer implement 'product plus service' system instead supplying their products to an anonymous food market.

The aim of this paper is to draw an agricultural sector-specific picture of servitization and discuss the differences between the business models of product-driven and servicedriven farms, also to analyse the needs and perspectives to develop agricultural policy in line with the success factors of the service-driven economic system and highlight the main new post-industrial rural policy trends, which corresponds to the needs of new farmers' generation oriented towards servitization of farming in the new programming period after 2020 .

\section{Theoretical background}

Although many developed countries in the world have been living in industrial economy for a centuries, the industrialization of the agricultural sector (in the literature of 2 nd half of 20 th century this phenomenon is often called as "modernization") have started not so long time ago. The authors of the economic history of agriculture say 
that massive industrialization of agriculture has started only after the Second World War. Agrarian sector experienced a real revolution in developed (northern) countries due to the widespread mechanization, electrification, irrigation and chemization of agricultural processes (Clunies-Ross, Hildyard, 2013). Modernized agricultural production system was based on a specific economic logic that allowed ensuring stable farm income level by increasing overall production volume and technical efficiency of production (Van der Ploeg, 2000). The success of an industrialized farming system was based on a business model combining three production strategies: extensive growth, intensification and specialization (Vidickiene, Melnikiene, 2014). The extensive growth strategy was implemented by increasing the amount of financial capital used in agricultural production, thus achieving the growth of production volumes and gaining a scale effect. The strategy of intensification was implemented using work process automatization, Green revolution technologies and standardized production organization methods, which allowed producing more output with the same amount of resources, as industrialization of agriculture emphasized not only the productivity of the land as before but also the labour productivity and return on capital. In addition, industrialization of agriculture stimulated to decrease multifunctional activities. The specialization strategy was implemented by choosing to produce only those products that allow a particular manufacturer to gain a competitive advantage. Specialized farms started to plant fields with just one crop species at a time over a very large area. Meat, milk, and egg production became largely separated from crop production and involved facilities that housed a single breed of animal, during a particular period of its lifespan, for a single purpose (e.g., breeding, feeding, or slaughter).

At the end of the 20th century, the success of business model oriented to the scale effect, intensification of productivity and narrow specialization have ended. This was a result of the growing list of factors that have a negative impact on the attractiveness of farming. First of all, the dramatic increase in labour productivity and the use of monetary and agricultural policy tools have eliminated the food shortages in developed countries caused by the World War II. Even the overproduction of agricultural goods in world markets was created in the middle of the 8 decade of $20^{\text {th }}$ century. By the end of $20^{\text {th }}$ century, the increase in gross production volumes became undesirable, not only due to the saturation of markets, but also due to increased opportunities for the food industry to supply non-agricultural raw materials and an increasing opposition to the 'dump' prices for surplus of products in the world markets (Renting, 2003). Farmers have lost the incentive to produce according to principle 'as much as possible', while the extensive growth strategy has become ineffective.

Another important factor decreasing the attractiveness of farming was constantly increasing costs of production; it reduced the opportunity to gain a huge leap in productivity by implementing an intensification strategy as it was at the beginning of industrialization. This is related partly to the 'technological treadmill' (Cochrane, 1979), pressing farms to invest continuously in new technologies so as not to lose out in the race for the lowest production costs. In addition, higher cost of production was 
a result of increased requirements for quality of products requested of food industry and retailers. Access to the market has become increasingly dependent on the farmer's ability to meet the criteria for product diversity and presence, flexibility to supply products and the availability of higher-quality product labels (Renting, 2003).

The third factor related with growing requirements for nature protection. Farmers were forced to make additional investments each year to comply with newly introduced environmental standards, animal welfare standards and sanitary measures. Farming strategy when one standard product is produced by intensive ways has been recognised as causing environmental damage and being criticized. This raised doubts about the benefits of a specialization strategy.

The fourth factor was the growing dynamism of the business environment. In the past, problems caused by the dynamism of the environment were most important in the manufacturing and service sectors, but in the last decade of the 20th century, farmers began to encounter new challenges related to the uncertainty of business conditions and the constant change of the current situation. In the1990s many developed countries have started to implement a free market and free trade model in their countries and activities in agriculture became even more risky. In particular, it was especially painful for specialized farms that produced mass agricultural products for export. Climate change is also a growing risk determinant to agricultural businesses.

The fifth important factor in reducing the attractiveness of farming was the globalization of the economy, which made the success of farming dependent not on personal efforts but on changes in liberalized markets for food, energy and other agricultural commodities. In addition, globalization of the economy has opened up new opportunities for developed countries to get cheaper food. For farmers from countries with a high standard of living have become difficult to compete with countries where expenditure for labour is very low.

All the above-mentioned factors reduced the viability of farmers' farms at the beginning of 21 century. According to M. Mazoyer and L. Roudart, "for the immense majority of the world's peasants, the international prices of basic food products are far too low for them to support themselves and renew their means of production, much less allow them to invest and grow" (2006, p. 14).

Rural policy has faced the challenge to find new measures to support the sustainability of farms. Aiming to reduce the growing risk of farming, new agricultural policy measures were introduced for farmers to change strategy of specialization to the strategy of diversification. Various combinations of activities were supported, using both related and unrelated diversification. However, the strategy of diversification of farming activities for some farmers has not become an effective tool for making a return from farming more safe. Assessing the growing impact of the above listed factors, they begin to consider farming as a risky and unattractive activity. Results of empirical studies show the situation that in the developed countries in the last two decades is not only the lack of successors to family farms, but also the lack of individuals who wish to take farms of retired farmers (Baker et al., 2016; Chiswell, 2012; Uchiyama et al., 2008). 
By our opinion, it should be responded to the challenges of the post-industrial society in the agriculture by gradually changing the dominant product-driven business model into a service-driven business model. The goals and means of the current agricultural policy should be transformed in line with the emerging new service-oriented farming business vision, since individual farmers or small groups of farmers do not have the capacity and ability to resist global food markets.

\section{Results}

Servitization in manufacturing companies is already widely and thoroughly studied in scientific literature (Lightfoot et al., 2013). Unfortunately, in contrast to the researchers, being active over the past three decades in creating of business models that integrate products and services of the companies and analyzing their success factors, researchers focusing their research on agribusiness and food industry are still giving little attention on business models in agriculture, assessing their sustainability and innovation (Ulvenblad et al., 2014). Although recently the issue of the sustainability of the agricultural sector has been analyzed very often, research is not oriented to promote innovative business model of farming by shifting from the "product-driven" to a "service-driven" model and focusing on predominant strategies in service-driven economy (see Figure 1).

Figure 1. Factors influencing changes in predominating strategies of industrial and servicedriven economies.

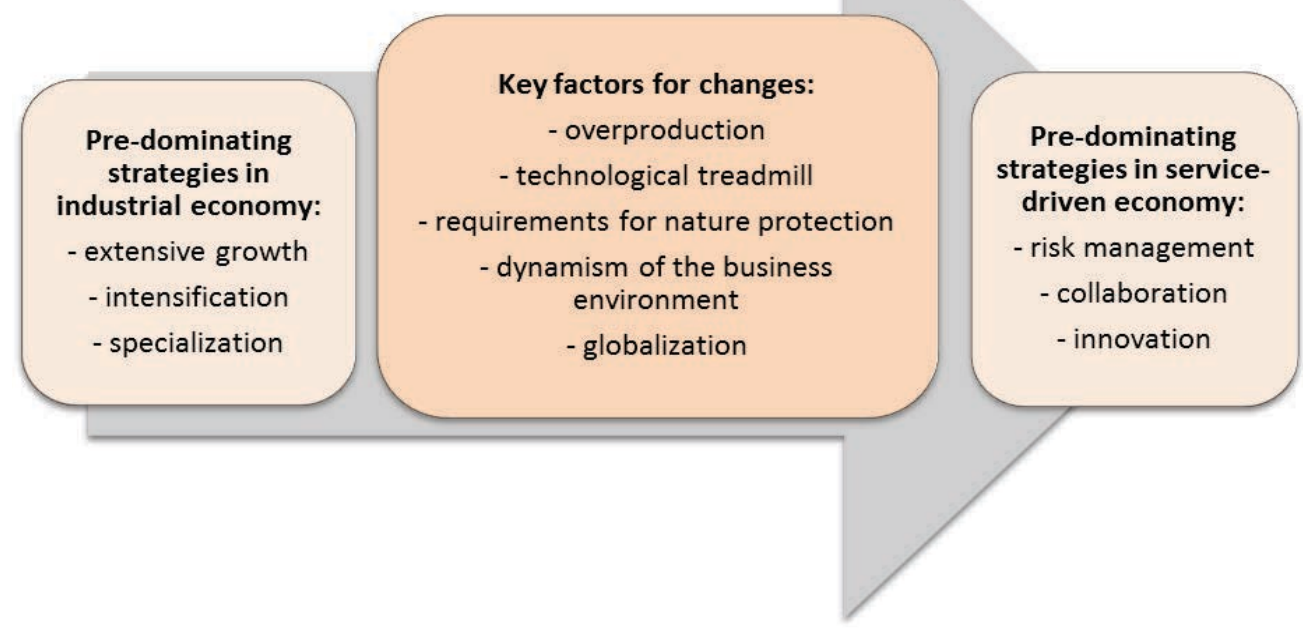

Source: created by authors.

Although the research is lacking on business servitization processes in agriculture and in other activities of farmers, it can be argued that a group of farmers is emerging, called the 'new farmers' generation', aiming to find alternatives to the business models established 
during the industrialization of the agricultural sector in the servitization framework. At the beginning, the vision of business model of a new farmers' generation was based on willingness to shorten food supply chain, by creating farmers' markets and starting direct selling of farm products to the end-users (Coster, 2004; Coster, Kennon, 2005; Guthrie et al., 2006). During the period of industrialization of agriculture, many intermediaries as processors, warehouses, transporters, and traders stepped between the farmer and endusers of their food products. Extremely large part of households in developed countries began to buy food at supermarkets, and purchasing food in farmers' markets became increasingly unpopular. Increasing number of intermediaries in the food supply chain had a profound impact on farmers' incomes. If in the sixties and seventies farmers received 40-50 percent of the food prices set by supermarkets, the share of farmers in developed countries since eight decade of the $20^{\text {th }}$ century is usually not more than 10 percent (Guthrie et al., 2006). The new generation of farmers has started new initiatives to develop alternative local food markets, revitalizing traditional farmers markets in cities, creating shops in their own farms, delivering food to the customer's home or workplace, etc. However, many such initiatives have failed, as small groups of farmers did not have the capacity and ability to resist global food markets.

However, it is important to note that the business model when farmers take direct sales in order to reduce the number of intermediaries involved in the supply chain are fundamentally different from the business model when a farmer creates long-time customer relationships by implementing 'product plus service' system instead supplying their products to an anonymous food market. In our opinion, the efforts made by farmers to apply servitizated business models to respond to the needs of consumers for fresh, locally produced food has a big potential. Although many farmers are using a simple business model for farming servitization by offering to produce desirable food box and delivery it to the consumers home or office (product-oriented service), empirical studies indicate that farmers have started to use more complex systems as 'product plus service' or 'resource access plus service'. It can be rental of a fruit or kitchen-garden, where residents of the city get the opportunity to grow their own vegetables and fruits, and they are also constantly consulted on how to do all the necessary work. Communitybased farming is also becoming more popular, when city residents partly finances a production process in the farm, or even engages in economic activities of farming from the very beginning of the production cycle with the aim to get products they want, and also to gain knowledge about agricultural production and spend their leisure time in the way interesting to them. There are also B2B models of service provision where small farmers provides services to the large farmers, for example, a special species of chicken are hatched on request, and then small farmer take them to a large farm, where they carry out further operations in the production cycle: growing up to the time of sale, slaughtering and selling. It allows to improve the quality of the agricultural products, to use more environmentally friendly technologies and to produce food products that is more nutritious for human health (Baluch et al., 2017). Servitized model is used in livestock sector (Pereira et al., 2016), crop protection (Pereira et al., 2018), etc. There is 
a growing demand for proposals of companies that have started use servitized business model and produce various agricultural machinery, to lease rather than buy farming equipment according to the needs of farmers (Corti et al., 2013). In successful cases the transformative power of business model innovation is really impressive.

\section{Discussions}

The history of economic system evolution indicates that it is not enough to focus on the technological innovations. Another important direction is development of innovative business models. Aiming to increase the productivity of workers in the beginning of the 20th century, an unprecedented jump was reached by applying F. Taylor and his followers' theory of "scientific management". In this century it is important not only the increase in labor productivity, but also the reduction of business risk, as the widespread use of information and communication technologies has not only high positive influence on the productivity, but also undesirable consequences. New opportunities to get requested information immediately and ability to manage this flow using modern information and communication technologies have created an extremely dynamic business environment and all previous business risk management practices have become ineffective. Services can be attributed to the least risky products, and their demand is growing. As a result, manufacturing companies are focusing on servitized business model aiming not only to increase its revenue, profit margin and the scale of sales but to create the opportunity to obtain loyal consumers and reduce the number of competitors. The fact that the financial crisis in 2008-2009 has streamed the business orientation towards the development of services, confirms the hypothesis that instability and unpredictability of the business environment are very important, if not the most important, factor for servitization of manufacturing and agriculture sectors.

Recently, scientists have started a discussion whether it is necessary to encourage entrepreneurs to create new businesses focused on new types of perspective services by increasing the tertiary sector, or to maximize the servitization of industry and agriculture activities. Research shows that the first path requires more social costs (Crozet, Milet, 2017). Therefore, a priority should be given for economic policy measures to promote the servitization of the production process in the manufacturing and farming.

Unfortunately, in the current documents defining agriculture and rural development in the EU, the term 'servitization' is not mentioned at all. Although new farmers' generation become an important organizational force for the development of the rural economy and community (Hewitt, 2009), there is given little attention to the interests and vision of farming of this generation when planning financial support tools. The new farmers are proposing completely different and innovative business models but their approach is not considered as an important factor that can influence the changes in culture of eating important for health of people, more careful use of natural resources and vitality of the countryside in the 21 st century. Although one part of the ideas of new farmers initiatives are in line with the EU programme requirements for the European Innovation Partnership (the EIP), aiming to promote a short food supply chain and 
diversification, creation of rules for the support measures were based on an industrial product-driven business model that focus to provide products for the anonymous market. Therefore, many steps needed to move to a service-driven business model are considered to be irrelevant to increase farm sustainability and are considered as not eligible for funding.

In our opinion, the EU needs to develop agricultural policy in the new programming period after 2020 in line with the success factors of the service-driven economic system, which corresponds to the needs of new farmers' generation oriented towards servitization of farming (Gedminaite-Raudone, Vidickiene, D., 2018). Servitization of farming is a transformational process that requires rethinking all aspects of the business: production structure and methods, marketing, pricing, service delivery infrastructure and financial management. Transition to a service-driven business model requires radical changes in the paradigm of agricultural and rural development policies. Summarizing the latest research on the serviced business model in the manufacturing sector (Kindstrom, 2010; Reim, 2015; Foss, Saebi, 2017) and the latest rural paradigms (networks, post-productive agriculture and rural development, endogenous rural development, place-based rural development), it is possible to assume that the greatest potential to help implement servicedriven business vision of the new generation of farmers' by economic policy measures is to support the use of collaboration strategies (Vidickiene, 2018). Researches that analyse the success factors in the shift of manufacturing companies to services demonstrate that in the service economy the most important is coordination of all the stakeholders and not previously important factors as the investment, the new production technologies and the specialization of employees. Most failures in implementing a service-driven business model are related to lack of collaboration with consumers. The collaboration is especially big challenge to farmers because the supply chain has become longer and they have lost their connection to their final consumer over the past half century. Therefore, the most important area requiring state aid becomes facilitation of tools for coordination of relations between economic actors. This means that support mechanisms must be based on the latest management theories emphasizing the business model based on the paradigm of co-creation (Ramaswamy, Ozcan, 2014) in service provision, where a part of the new value is generated not by services provider but by the clients. The degree of inclusion of a service consumer in a newly created value can be varied, but the service provider always makes their own contribution. Considering this fundamental change in the value creation process, the key future objective of improving the EU's agrarian and rural policies is to provide support measures to innovative cooperation between farmers, as service providers, and their consumers. The key to success should become the implementation of a variety of new collaboration models reducing farming risk and generating synergetic effect by value co-creation.

\section{Conclusions}

1. New generation of farmers have emerged in the $21^{\text {st }}$ century aiming to find alternatives to the business models that existed during the industrial stage of the agricultural sector development. 
New farmers' generation often is described as a group of innovative farmers that focuses on totally different lifestyle and new livelihoods appeared in post-industrial business environment. It can be argued that the business vision of a new generation has a great potential because it is based on the success factors of post-industrial economy focused on service-driven business model.

2. Conservative policy-makers are quite sceptical about the ideas and opportunities offered by the new generation of farmers to create a sustainable source of income for the food made to order or other services. To a large extent, this is due to a lack of clear and scientifically based guidelines how to organise a servitized business model, components if this model and which strategies can be most effectively used for it in the current business environment.

3. The use of various government programs supporting innovative service-driven business farms can become an effective tool helping not only to develop agriculture and the economy of rural regions, but also to build a new, socially responsible culture of consumption, by development of healthier eating and eco-friendly lifestyle habits.

\section{Conflict of interests}

The authors declare no conflict of interest.

\section{References}

1. Baker, J. R., Lobley, M., Whitehead, I. (2016). Keeping it in the family: international perspectives on succession and retirement on family farms. Oxford: Routhledge Press.

2. Baluch, N., Ariffin, A. S., Abas, Z., Mohtar, S. (2017) Servitization in Malaysian poultry contract farming: a critical overview, International Journal of Supply Chain Management, 6(1), 259-265.

3. Barbieri, C., Mahoney, E. (2009). Why is diversification an attractive farm adjustment strategy? Insights from Texas farmers and ranchers, Journal of rural studies, 25(1), 58-66.

4. Chiswell, H. M. (2014). The importance of next generation farmers: a conceptual framework to bring the potential successor into focus, Geography Compass, 8(5), 300-312.

5. Clunies-Ross, T., Hildyard, N. (2013). The politics of industrial agriculture. Routledge.

6. Cochrane, W. W. (1979). The development of American agriculture: a historical analysis. Minnesota Press.

7. Corti, D., Granados, M. H., Macchi, M., Canetta, L. (2013). Service-oriented business models for agricultural machinery manufacturers: looking forward to improving sustainability. In Engineering, Technology and Innovation (ICE) \& IEEE International Technology Management Conference, June, 2013, 1-8. 
8. Coster, M. (2004). Report on the role of "new generation" farmers' markets. Department of Primary Industries, Bendigo, Victoria, Australia.

9. Coster, M., Kennon, N. (2005). The role of new generation farmers' markets in rural communities. Rural Industries Research and Development Corporation, Australia.

10. Crozet, M., Milet E. (2017). The servitization of French manufacturing firms. In L. Fontagné and A. Harrison (eds.), The Factory-Free Economy. Outsourcing, Servitization, and the Future of Industry, Oxford University Press.

11. Fairbairn, M., Fox, J., Isakson, S.R. (2014). Introduction: new directions in agrarian political economy, Journal of Peasant Studies, 41(5), 653-666.

12. Foss, N. J., Saebi, T. (2017). Fifteen years of research on business model innovation: How far have we come, and where should we go?, Journal of Management, 43(1), 200-227.

13. Gedminaite-Raudone, Z., Vidickiene, D. Agricultural policy in the servicedriven economic system, Lithuanian Institute of Agrarian Economics. Conference "The CAP and national priorities within the EU budget after 2020", 12 June 2018, Lidzbark Warmiński, Poland.

14. Guthrie, J., Guthrie, A., Lawson, R., Cameron, A. (2006). Farmers' markets: the small business counter-revolution in food production and retailing, British Food Journal, 108(7), 560-573.

15. Hamilton, N. D. (2011). America's new agrarians: policy opportunities and legal innovations to support new farmers, Fordham Environmental Law Review, 22, 523-562.

16. Kindström, D. (2010). Towards a service-based business model - key aspects for future competitive advantage, European Management Journal, 28(6), 479-490.

17. Lightfoot, H., Baines, T., Smart, P. (2013). The servitization of manufacturing: A systematic literature review of interdependent trends, International Journal of Operations \& Production Management, 33(11/12), 1408-1434.

18. Mazoyer, M., Roudart, L. A. (2006). History of world agriculture: from the Neolithic age to the current crisis. Eartscan, London/Sterling VA.

19. Organization for Economic Cooperation and Development (OECD). (2006). Rural Policy Reviews. The New Rural Paradigm: Policies and Governance. Paris, OECD.

20. Pereira, A., Carballo-Penela, A., Gonzalez-Lopez, M. I., Vence, X. (2016). A case study of servicizing in the farming-livestock sector: organisational change and potential environmental improvement, Journal of Cleaner production, 124, 84-93.

21. Pereira, A., Carballo-Penela, A., Guerra, A., Vence, X. (2018). Designing a policy package for the promotion of servicising: A case study of vineyard crop protection in Galicia (Spain), Journal of Environmental Planning and Management, 61(2), 348-369. 
22. Ramaswamy, V., Ozcan, K. (2014). The co-creation paradigm. Stanford University Press.

23. Reim, W., Parida, V., Örtqvist, D. (2015). Product-service systems (PSS) business models and tactics - a systematic literature review, Journal of Cleaner Production, 97, 61-75.

24. Renting, H., Marsden, T. K., Banks, J. (2003). Understanding alternative food networks: exploring the role of short food supply chains in rural development, Environment and planning, 35(3), 393-411.

25. Suwan, P., Opatpatanakit, A. (2015). Motivations and achievements for midcareer change into farming occupation, International Journal of Agricultural Technology, 11(5), 1059-1073.

26. Uchiyama, T., Lobley, M., Errington, A., Yanagimura, S. (2008). Dimensions of intergenerational farm business transfers in Canada, England, the USA and Japan, Japanese Journal of Rural Economics, 10, 33-48.

27. Ulvenblad, P., Hoveskog, M., Tell, J. et al. (2014). Agricultural business model innovation in Swedish food production: the influence of self-leadership and lean innovation. In: Proceedings of the DRUID Society Conference on Entrepreneurship-Organization-Innovation, Copenhagen Business School.

28. Van der Ploeg, J. D., Renting, H., Brunori, G. (2000). Rural development: from practices and policies towards theory, Sociologia Ruralis, 40(4), 391-408.

29. Vandermerwe, S., Rada, J. (1988). Servitization of business: adding value by adding services, European Management Journal, 6(4), 314-324.

30. Vidickiene, D. (2018). Adapting to the needs of new farmers' generation: theoretical foundations for rural policy, Public Policy and Administration, $17(1), 54-67$.

31. Vidickiene, D., Melnikiene, R. (2014). Evolution of rural policy: monograph. - Vilnius: Lithuanian Institute of Agrarian Economics. 272 p. ISBN 978-9955481-44-7. 